\title{
The Devdoraki Glacier catastrophes, Georgian Caucasus
}

\author{
Levan G. TIELIDZE ${ }^{1,5}$, Roman M. KUMLADZE², Roger D. WHEATE ${ }^{3}$ and \\ Mamia GAMKRELIDZE ${ }^{4}$
}

\begin{abstract}
This study analyses the Devdoraki Glacier surge type catastrophes since 1776, lead to human casualties, destruction of settlements and the international road in the Georgian Caucasus. According to archival data, at least six ice and ice-rock avalanches fell from the Devdoraki Glacier onto the Tergi (Terek) River valley during the period 1776-1876, the largest on June 18, 1776 and on August 13, 1832. The first blocked the Tergi River for three days and was breached catastrophically; the second was $\sim 100 \mathrm{~m}$ high and $\sim 2 \mathrm{~km}$ wide and its breach started after 8 hours. The most recent hazard occurred on May 17, 2014 killing nine people, and destroyed the Trans-Caucasus gas pipeline, Dariali Hydropower Plant (HPP) and international road. Using aerial and satellite imagery - Landsat, ASTER, SENTINEL, PLEIADES along with the $30 \mathrm{~m}$ resolution Advanced Spaceborne Thermal Emission and Reflection Radiometer Global Digital Elevation Model (ASTER GDEM; 17 November 2011) we have reconstructed this event. On the basis of subsequent detailed field observations, new geological and tectonic maps of the study region have been compiled. After that collapse we have registered $180 \mathrm{~m}$ advance of the Devdoraki Glacier snout between 2014 and 2015, which was mostly caused by rock-ice avalanche deposits. This part of the glacier should be monitored continuously as it can raise debris flow activity in the future. We consider the main hypotheses behind these events, namely a) tectonic and seismic, b) permafrost, c) volcanic and d) morphological factors; interpret the data for mechanisms and velocities of the catastrophic movement and argue that the 2014 event should not be classified as a glacier surge, although the possibility of similar glacial surges can not be excluded. The Kazbegi-Jimara massif should be considered as a natural laboratory that enables the investigation of rock-ice avalanches and glacial mudflows.
\end{abstract}

Keywords: glacial hazard, rock-ice avalanche, debris flow, Devdoraki Glacier, surging glacier, Greater Caucasus

\section{Introduction}

Glaciers respond to changes in climate, translating the climatic signal into clearly observable changes in the landscape (Oerlemans, J. 2005). The global trend of glacier retreat in reaction to global climate change (IPCC, 2013) has implications for both ecosystem functions and human development. Glaciofluvial deposits transported by meltwater runoff are an important input for aquatic ecosystem biodiversity (Muhlfeld, C.C. et al. 2011). Mountain meltwater runoff is also an important water source for downstream populations at scales ranging from small communities to large metropolitan centers (Lutz, F. et al. 2014).

Natural disasters that have become more frequent due to climate change are often related to mountain glaciers. These are known

\footnotetext{
${ }^{1}$ Department of Geomorphology, Vakhushti Bagrationi Institute of Geography, Ivane Javakhishvili Tbilisi State University, 6 Tamarashvili Ave., Tbilisi, 0177; Department of Earth Sciences, Georgian National Academy of Sciences, 52 Rustaveli Ave., Tbilisi, 0108, Georgia. Correspondent author's e-mail: levan.tielidze@tsu.ge

${ }^{2}$ Laboratory of GIS and Cartography, Vakhushti Bagrationi Institute of Geography, Ivane Javakhishvili Tbilisi State University, 6 Tamarashvili Ave., Tbilisi, 0177, Georgia.

${ }^{3}$ Natural Resources and Environmental Studies, University of Northern British Columbia, 3333 University Way, Prince George, BC, V2N 4Z9, Canada.

${ }^{4}$ Geological Mapping Division, Department of Geology, National Environmental Agency, Ministry of Environment Protection and Agriculture of Georgia, 150 Agmashenebeli Ave., Tbilisi, 0112, Georgia.

${ }^{5}$ School of Geography Environment and Earth Sciences; Antarctic Research Centre, Victoria University of Wellington, PO Box 600, 6140, Wellington, New Zealand.
} 
as glacial hazards, which are highly dangerous and unpredictable natural hazards, but characteristic of many mountain regions (Evans, S.G. and Clague, J.J. 1994). They pose threats to population, infrastructure, human activities and economic development. The earliest known evidence of devastating glacial hazards in the Alps dates back to medieval times (RICHARD, D. and GAY, M. 2003). Glacial hazards include outbursts from moraine and glacier-dammed lakes, glacier avalanches, and landslides/debris flows in the glacier environment. These events have taken place more recently in the context of dramatic retreat of glaciers in response to climate change (Dyurgerov, M.B. and Meier, M.F. 2000). It is expected that the frequency, and in some cases the magnitude, of glacial hazards will increase due to global warming and consequent glacier retreat (REYNOLDS, J.M. 2003).

Glacier disasters are widespread in the Greater Caucasus, involving the detachment of large glacier masses (several million $\mathrm{m}^{3}$ ) and their rapid movement down valleys, with speeds of tens of metres per second for distances up to tens of kilometres. Sometimes they reach the scale of debris flow disasters, leading to large changes in valley floors, significant damage to infrastructure and casualties. The Kazbegi-Jimara massif has a long record of such extreme rock-ice avalanches and glacial mudflows (Figure 1).

The largest ice-rock avalanche was recorded on 20 September 2002 on the Russian side (North Ossetia) of the mountain. On the north-eastern face of Mt. Kazbegi, 150 million $\mathrm{m}^{3}$ of rock and ice failed and fell onto Kolka Glacier, triggering an ice-rock-debris flow down the valley with speeds up to 80 $\mathrm{m} / \mathrm{sec}$. More than 100 people were killed (Evans, S.G. et al. 2009).

On May 172014 at 09:33 a.m. in the Dariali (Tergi) gorge (Georgian Caucasus, Kazbegi region), in the confluence of the Tergi and Amali (Devdoraki) rivers, a catastrophic rock-ice avalanche and glacial mudflow took place blocking the strategic infrastructure of the country (Photo 1). The Trans-Caucasus gas pipeline and hydropower plant were damaged. Mudflow damaged the high-voltage power transmission tower, the border guard base was isolated from the outside world, as well as the customs checkpoint and residence of the Patriarchate of Georgia. The disaster resulted in the death of nine people. About 200 people were evacuated by helicopter from the border crossing checkpoint and nearby areas. Thus, scientific study of this natural disaster is of practical importance.

In this article we present the Devdoraki Glacier change and glacial disasters which have occurred since 1776 and reconstruct/analyze the latest glacial hazard on 17 May, 2014.

\section{Study area}

The Kazbegi-Jimara massif is second only to the Elbrus as a modern glaciation area in the Caucasus region (Tielidze, L.G. and WhEATE, R.D. 2018), and is the heart of glaciation in the Tergi River basin, located in the northern Greater Caucasus (Tielidze, L. 2017). Kazbegi (Mkinvartsveri) is a dormant volcano which has a principal double cone and several side cones. The main cone erupted about $185,000 \pm 30,000$ years ago, while the side cone of New Tkarsheti erupted about 6,000 years ago (Chernyshev, I.V. et al. 2002). In view of present volcanic activity Mt. Kazbegi can be regarded as dormant. Geochemical observations and analyses suggest the proximity of magmatic bodies indicated by degassing of magmatic reservoirs (PolyaK, B.G. et al. 2000). The Kazbegi-Jimara slopes generate valley type glaciers: Mydagrabyn, Maili, Kolka (Russia), Suatisi, Mna, Gergeti, Abano, Chachi and Devdoraki (Georgia). The hanging-valley type Devdoraki Glacier $\left(4.40 \pm 0.12 \mathrm{~km}^{2}\right)$ is known for its powerful rock-ice avalanches in $18^{\text {th }}-21^{\text {th }}$ centuries.

The geological structure of the region involves intrusive and metamorphic rocks of Paleozoic age and Jurassic sediment and weakly metamorphic rocks as well as Quaternary volcanic, alluvial, deluvial, proluvial, colluvial and glacial sediments (Tielidze, L.G. et al. 2019) (Figure 2). 


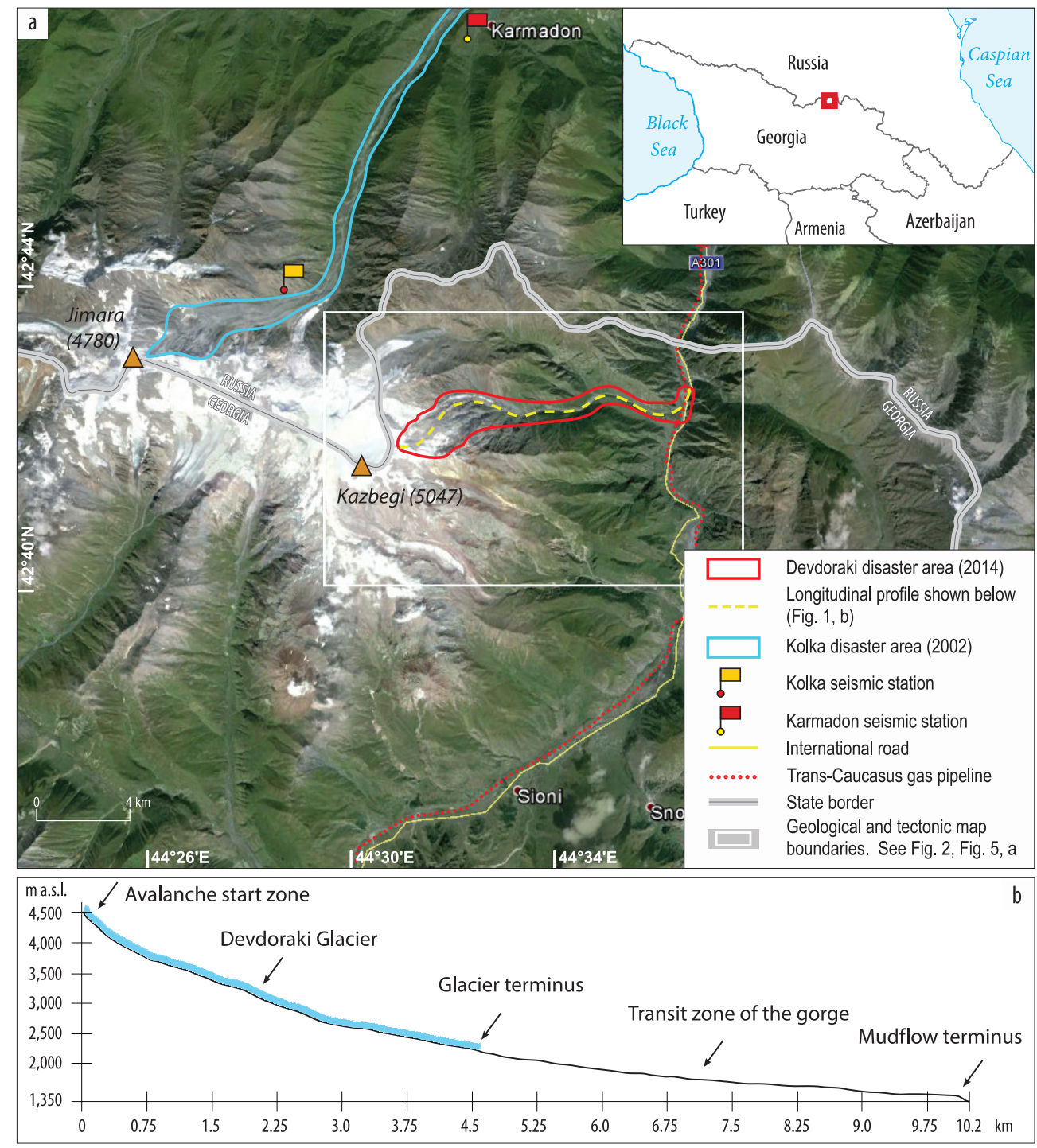

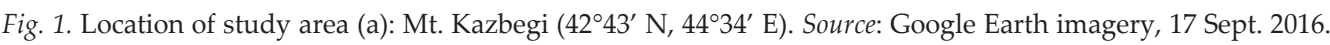
Longitudinal cross section along the avalanche and distal mudflow track (b). Source: Based on ASTER GDEM, 2011.

Jurassic sediments are widely represented, in which researchers have highlighted and studied lithofacial suites of different ages (Topchishvili, M.V.et al. 2006). The oldest is the Sinemurian (J1s) suite of Khde (Kistanka), which is constructed from weakly metamorphic thin layered sandstone (aspid) slates of flyschoid texture, quartzites, gravelites and occasional middle layers of conglomerate.

The volcanogenic massif of Kazbegi (Dzotsenidze, N. 1985) has generated the lava flows of Tsdo and Chachi and two branches of the Khde flow - the Amali and Gveleti flows. Exogenous-continental sedi- 


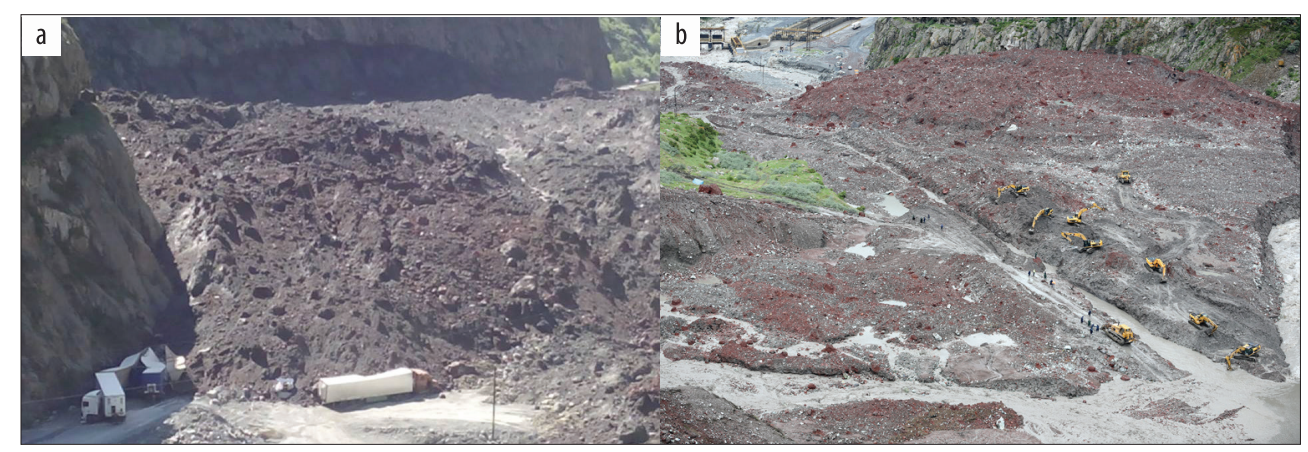

Photo 1. Mudflow terminus area and damaged international highway on 17 May 2014 (a), and 18 May 2014 (b). (Photo by INTERPRESSNEWS).

ments are represented by genetical diversity in lithological composition and origin, such as glacial, deluvial, proluvial, colluvial and lahar formations (KipIANI, I. et al. 1983). This tectonically active area features geothermal activity, including several hot springs in the area of the Kazbegi massif, revealed by field observations (PolyaK, B.G. et al. 2000) and (Zautashvili, B. and Mkheidze, B. 2012).

The climate above $3,400 \mathrm{~m}$ a.s.l. is moderately humid around the Kazbegi massif. Two zones are distinguished: the nival $(3,400-4,300 \mathrm{~m})$ and glacial (above 4,300 m). The average annual precipitation is 1,000$1,200 \mathrm{~mm}$. The number of days with precipitation amounts to 170 per year, falling only as snow in the glacial zone. The mean winter temperature is $-10{ }^{\circ} \mathrm{C}$ and the mean summer temperature is $2.2^{\circ} \mathrm{C}$ in the nival zone. The mean wind speed is $6.2 \mathrm{~m} / \mathrm{sec}$, with an average number of 12 stormy days per month in winter (NAKHUTSRISHVILI, G. et al. 2005).

\section{History of disasters}

The surging-type Devdoraki Glacier was probably the most famous glacier of the Greater Caucasus in the $19^{\text {th }}$ century. The well-known "Kazbegi blockages" stopped transportation between Russia and Georgia, which at the time had just joined the Russian Empire. The first recorded significant "collapse" occurred in June 1776. The valley of the Tergi River was blocked for three days, a temporary lake formed, before the dam was broken, flooding several auls (mountain villages), even at a height of $\sim 76 \mathrm{~m}$ above the river. This blockage was first described by ReynegGs, D. (1884).

There was no official information about the blockage in 1817 . There is only a brief note from General Ermolov's diary: “In October, the collapse of the mountains of the Caucasus snow crashed. At first its height was $\sim 80$ 100 metres. The flow of the Tergi River was stopped for almost 24 hours. The ice mass did not melt even after a year" (REYNEGGS, D. 1884).

There is more information about the blockage of 1832. An ice mass in the night from August 12 to August 13 blocked the Tergi River between the Gveleti Village and Khde River confluence ( $\sim 2.2 \mathrm{~km}$ long). The river flow was stopped for 8 hours. The collapsed ice mass was $\sim 100 \mathrm{~m}$ in height in the Tergi River valley and $\sim 15$ million $\mathrm{m}^{3}$ in a volume. The total deposited volume, including the Amali River valley amounted to 22 million $\mathrm{m}^{3}$ (DINIK, N.YA. 1890). It was a much greater amount than usual for glacier avalanches in the Alps (Неувкоск, W. 1935). The road was restored from the dam after two years, and completely blocked up again only five years later (DiniK, N.YA. 1890).

Since 1832, several new blockages were forecasted, but either the ice-debris masses did not reach the Tergi River or the fore- 


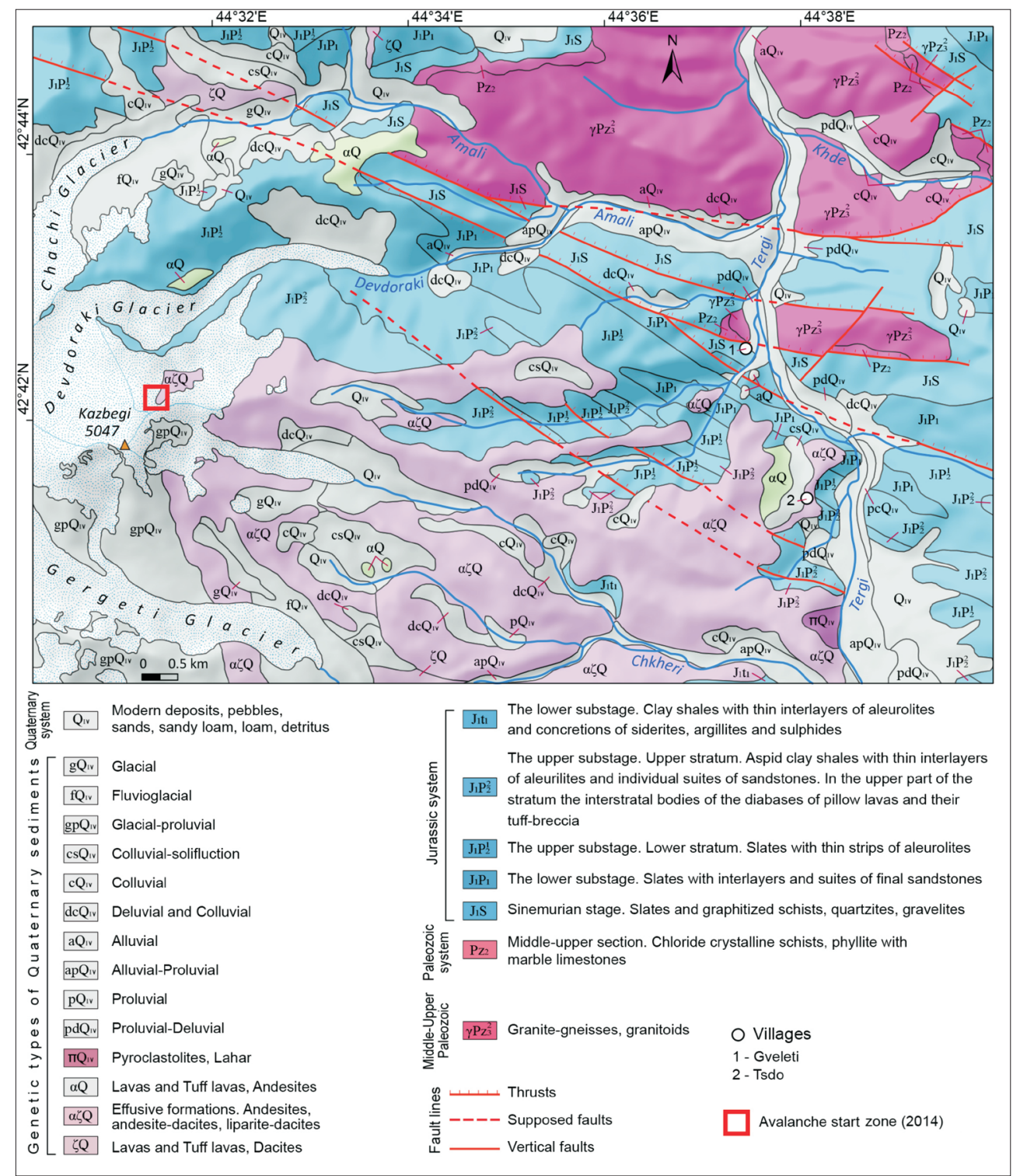

Fig. 2. Updated geological map of the study region based on 1: 50,000 scale geological map (k_38_42_v, 1983). For the map boundaries see Fig. 1 .

casts failed altogether. E.g. in 1866-1867 the Devdoraki Glacier advanced, raising alarm and forcing researchers to monitor its position. But the blockage was developed slowly and the Tergi River valley was not blocked (SтAткоWsкy, B.I. 1877) (Figure 3).
In 1876, again there was a danger of a blockage, since the glacier greatly increased and advanced by 150 metres (Figure 3, c). The true cause of these blockages would be easy to find if we had accurate information about the phenomena that preceded the ob- 


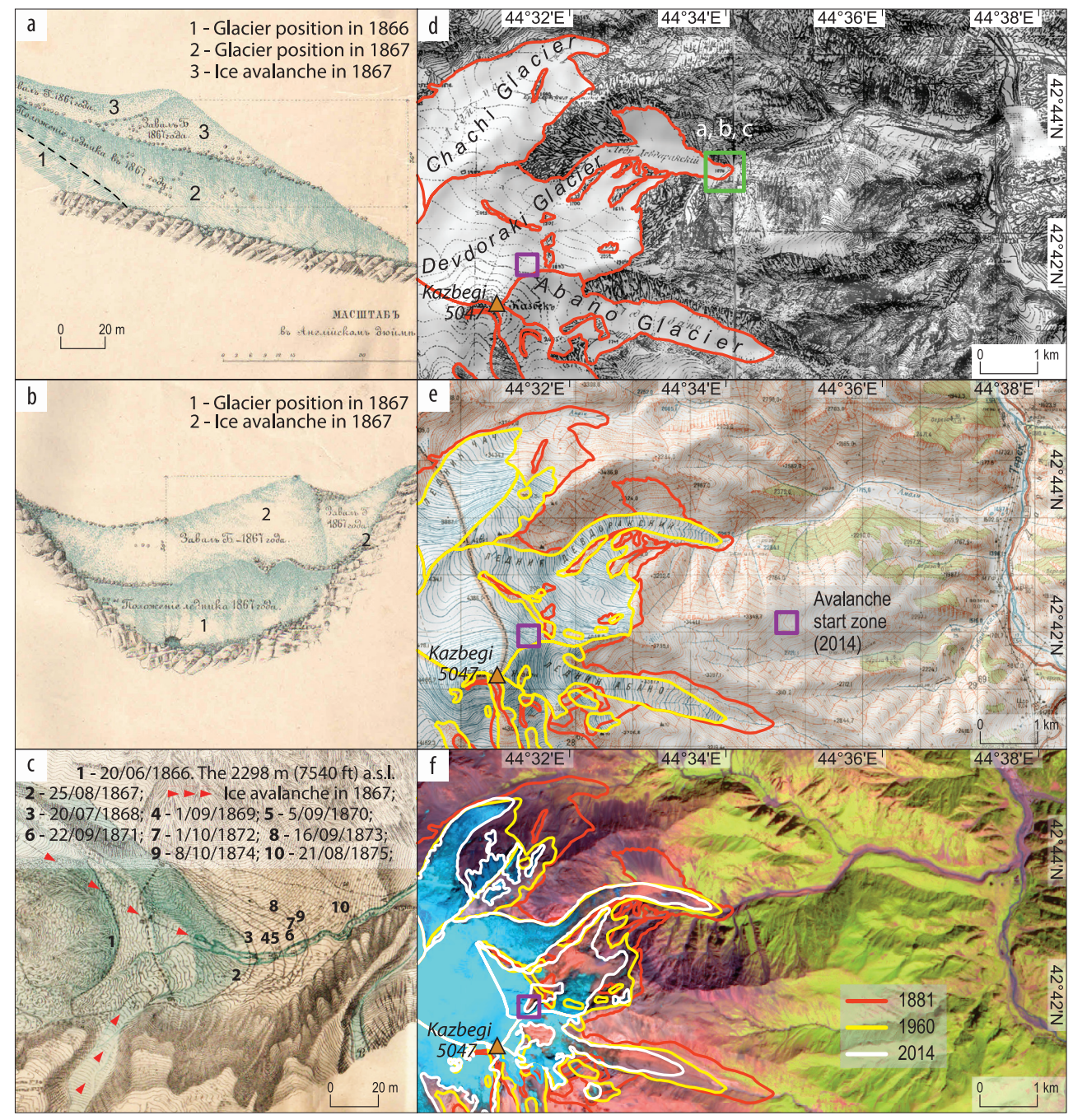

Fig. 3. The Devdoraki Glacier longitudinal profile (a) in 1866-1867; its transversal profile (b) in 1867 by SтAткошsкy, B.I. (1877). The Devdoraki Glacier advance (c) in 1866-1875 by Dinik, N.YA. (1890). The Chachi, Devdoraki and Abano glaciers reduction in 1881 (d) on military topographic map (1: 42,000); in 1960 (e) on military topographic map (1: 50,000); and between 1881 and 2014 (f) by Landsat 8 (28 August 2014).

structions and accompanied them: "we do not know exactly what is most important, which part of the glacier breaks, only the lower end of it falls or ... those ice that lie much higher ... do not know if the ice remains in the valley after the collapse ... and what is at that time a glacier. There are only conjectures and hypotheses" (Dinik, N.YA. 1890).
VARDANYANTS, L.A. (1932), analyzed the causes of the discharges of the Devdoraki Glacier, as well as the Genaldon disaster of 1902 on the Kolka Glacier. He believed that they were caused by earthquakes and formed by the landslides of the "hanging floor" characteristic of the Kazbegi massif glaciers. According to the observations of 1926-1928 he 
noted that on many glaciers the feeding area is interrupted by an "ice wall hanging over a steep rocky cliff" about 50 m thick, from which "whole ice bands must come off" during earthquakes. In addition, he concluded that water didn't play a significant role. As the Devdoraki Glacier has an area of about 9 $\mathrm{km}^{2}$, an avalanche of this order would require a precipitation of $\sim 3,000 \mathrm{~mm}$ during the year, which is improbable in the Kazbegi region.

Information on further observations of the Devdoraki Glacier, up to the first decade of the $20^{\text {th }}$ century, is given in the work of Duкноvsкiу, A.I. (1915), who investigated the state of other glaciers of the Kazbegi massif, where collapses or movements also occurred - Abano, Mna, Gergeti and Chachi. PAnov, V.D. (1993) later used DukhovsкiY' s data on the fluctuations of the Devdoraki Glacier in 1863-1893 and 1905-1912. After 1885 the glacier experienced fluctuations, and the advances of its terminus occurred repeatedly, for example, in 1886-1887, as well as in 1893-1904, when the glacier advanced by 45 and $55 \mathrm{~m}$ respectively. As a result, over the entire period from 1881 to 1970, the glacier retreated by only $16 \mathrm{~m}$ (PANov, V.D. 1993). However, two topographic maps from 1881 and 1960 showed a major glacier retreat of $\sim 190 \mathrm{~m}$ (Figure 3, d, e). Overall we have measured $\sim 400 \mathrm{~m}$ terminus retreat between 1881 2014 (before the collapse) (Figure 3, d-f) and $\sim 75 \mathrm{~m}$ and $\sim 180 \mathrm{~m}$ advance phases between 2002-2006 and 2014-2015.

In the 1960s, much work was devoted to the study of the glaciers of Kazbegi massif by Tsomaia, V.SH. (1980). According to his investigation the Devdoraki was the fastest moving glacier in the Caucasus. While most Caucasus glaciers were retreating, the Devdoraki Glacier snout was stationary between 1912 and 1960s and even advanced in 1969-1979. He believed that this advance, also observed on other Kazbegi massif glaciers, was associated with a large accumulation of precipitation in the firn areas in 1955-1970. As for the causes of the previous debris flow, Tsomaia supported the opinion of SтAткоvsкy, B.I. (1877), that the free passage of the ice into the narrow gorge of the Devdoraki River was hindered. As advance continued, the ice accumulated to such a thickness in the gorge that a temporary dam was formed. The water held behind this barrier eventually burst through, carrying large amounts of ice and rubble. Tsomain considered the possible danger of new blockages. Subsequently, there were many expeditions and investigation from the 1960s to 2017 (Asoyan, D.S. and Rototaeva, O.V. 2016).

\section{Data and methods}

Large-scale topographic maps (1: 42,000) from the second Caucasus topographic survey (1880-1910) were used to evaluate the Devdoraki Glacier outline (Table 1). The oldest topographic maps were replaced in 1960, under the former Soviet Union with 1: 50,000 scale topographic maps from 1950 to 1960 with a contour interval of $20 \mathrm{~m}$. We used these 1960s georeferenced maps from the latest Caucasus glacier inventory (TiELIDze, L.G. and Wheate, R.D. 2018). As the 1880s maps were only available in printed form, we scanned these at $300 \mathrm{dpi}$ with $7 \mathrm{~m}$ ground resolution and co-registered using the 11 July

Table 1. List of the maps and satellite images scenes used in this study.

\begin{tabular}{l|c|l|l}
\hline \multicolumn{1}{c|}{ Year, date } & Resolution, $\mathrm{m}$ & \multicolumn{1}{|c}{ Type of imagery/map } & \multicolumn{1}{c}{ Scene ID } \\
\hline 1881 & 7 & $1: 42,000$ topographic map & 222_26_II \\
1960 & 5 & $1: 50,000$ topographic map & k_38_42_v \\
1983 & 7 & $1: 50,000$ geological map & k_38_42_v \\
16.05 .2014 & 15 & ASTER & AST_L1T_00305162014080121_2 \\
& & & 0150621034017_9465 \\
11.07 .2014 & $5-30$ & Landsat 8 & LC81700302014192LGN00 \\
18.05 .2014 & 2 & PLEIADES & PL1A_20140518_081358 \\
\hline
\end{tabular}


2014 Landsat 8 image as a master (TiELIDZE, L.G. 2016). Offsets between the images and the archival maps were within one pixel (15 $\mathrm{m}$ ) based on an analysis of common features identifiable in each data set. We re-projected maps in Universal Transverse Mercator (UTM) coordinates, zone $38 \mathrm{~N}$ on the WGS84 ellipsoid, to facilitate comparison with modern image data sets.

High-resolution satellite instruments such as Landsat L8 OLI/TIRS (Operational Land Imager and Thermal Infrared Sensor), with 15-30 m horizontal resolution available since 2013, and Advanced Spaceborne Thermal Emission and Reflection Radiometer (ASTER) imagery with $15 \mathrm{~m}$ resolution available since 2000, and others of their class help in recognizing important details of natural hazards; e.g., avalanche and debris-flow traces, glacier crevasses, and lakes and their changes over time (Кӓ̈̈в, A. 2002; Кё̈̈в, A. et al. 2003).

We have used an ASTER satellite image captured one day before the disaster in cloud free weather conditions on 16 May 2014 and Landsat 8 image approximately two months after the disaster in partially cloudy weather on 11 July 2014. Georeferenced images were downloaded using the EarthExplorer (http:// earthexplorer.usgs.gov/) and Reverb/ECHO tools (http://reverb.echo.nasa.gov/). We used the Landsat 8 panchromatic band, along with a colour composite scene for each acquisition date, combining shortwave infrared, near infrared and red for Landsat, and near-infrared, red and green for ASTER images. For both Landsat and ASTER images we used pan-sharpened tools in ArcGIS 10.2.1 software.

We used the $2 \mathrm{~m}$ resolution PLEIADES 1A multispectral (Blue, Red, Green and Near Infrared) imagery for post event analysis (http://scanex.ru/). The PLEIADES 1A sensor was launched in December, 2011. Like other $0.5 \mathrm{~m}$ resolution sensors, this satellite sensor collects both panchromatic and RGB and NIR (2 m) multispectral data, and is a great option for site monitoring or change detection analyses.
The $30 \mathrm{~m}$ resolution ASTER Global Digital Elevation Model (GDEM, 17 November 2011) was used to determine slope and hypsometric profile from the Rock-ice avalanche up to its final stop. The DEM has been downloaded from NASA LP DAAC Collections (http://earthexplorer.usgs.gov/).

In addition, we used the large scale (1: $50,000)$ geological map created in 1983. We conducted several field trips to detail geomorphological and geological survey over the last years. Based on field information and the geological map, we created modern geological and tectonic maps of the study region.

We used the global permafrost zonation index map by Gruber, S. (2012), in order to observe the relationship between the last glacier avalanche and permafrost intensity.

\section{Reconstruction of the 17 May event}

On the ASTER image from 16 May 2014, the start zone of the rock-ice avalanche was already unstable, because a trace of rock fall is observed (Figure 4, a). The result of the disaster is shown on the Landsat image from 11 July 2014 (Figure 4, b) and on the PLEIADES image from 18 May 2014 (Figure 4. c). The field data and aerial images from the helicopter enabled us to reconstruct the event.

Unlike phenomena which occurred in the gorge in the past, when ice masses were detached from the glacier terminus, the rock-ice avalanche formation zone of 2014 is located at a relatively high benchmark, at a height of $\sim 4,500 \mathrm{~m}$ on the steeply inclined $\left(60-75^{\circ}\right)$ north-east slope of the Kazbegi peak (Photo $2, \mathrm{a}, \mathrm{b})$. In the south-eastern part of the Devdoraki Glacier's feeding zone, the rockavalanche involved rock and glacier components among large snow masses (NEA 2014). The collapsed mass was transformed into the rock-ice avalanche, which was divided into three flows and rushed down the steep icetongue surface at high speed (Photo 2, c, d).

One of the flows jumped over the rock ledge spraying the transformed mass onto the steep slope, but most of the material 


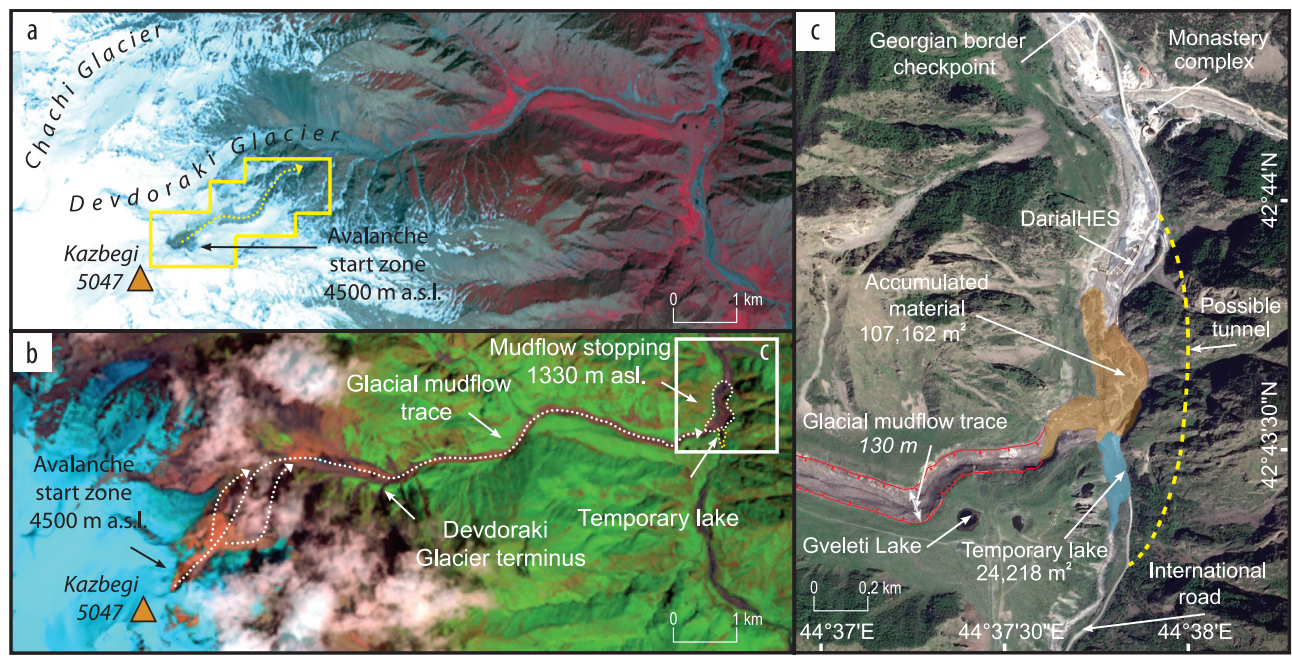

Fig. 4. ASTER image, 16 May 2014 (a); Landsat L8 image, 11 July 2014 (b); PLEIADES image, 18 May 2014 (c).

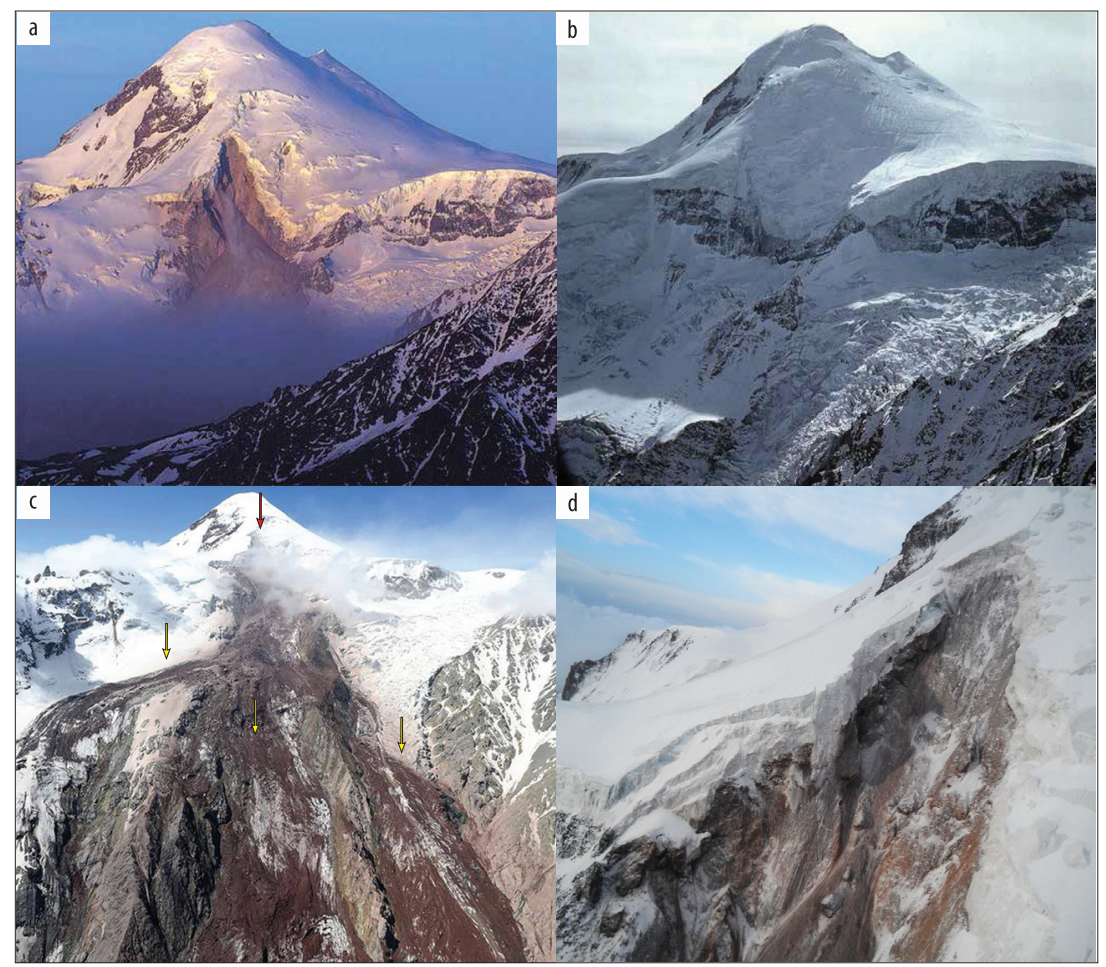

Photo 2. Mt. Kazbegi and the heart of rock-ice avalanche genesis on 17 May 2014 (a). An archive photo (1987) about the same site (b). A helicopter photo taken on 17 May 2014: red arrow shows avalanche start zone, yellow ones show the three flows of the rock-ice avalanche (c). Avalanche start zone close view 18 May 2014. Photos taken by: Gotsiridze, G. (a, c), Rototaeva, K.P. (b), Gaprindashvili, M. (d). 
collapsed instantly into the glacier again. A reddish-pink trace was observed in the high benchmarks of the southern slope in the form of a large spot (Photo 3, a). The largest flow placed the central part of the ice-tongue in the dynamic zone and this suffered strong deformation and fragmentation into distinct ice blocks (NEA 2014).

Below this section all flows were united in a single flow of grandiose volume and rushed down to the gorge at a high speed and in its way took away the glacier deposits and weathered material in the Devdoraki River bed and on its slopes.

After joining the Devdoraki and Amali rivers, the flow moved in the curved bed of the trapezoidal cross-section developed in the glaciofluvial-mudflow sediments, with an average depth of 20-25 m. In the Gveleti Lake meridian the river bed turns sharply to the north-east. In addition, the trapezoidal section's relatively wide bed transforms in- stantly into a narrow "V" $\mathrm{V}$-shaped cross-section bed, and its throughput is considerably limited. Therefore, in the location of a sharp bend the short-term uneven temporary damming of the mudflow took place. Due to the temporary damming of the flow, its driving force increased and the flow was thrown in the direction of the confluence of the Tergi River, reaching the rocky cliff composed of granitoids and deposited solid material transported by the mudflow at its foot. In addition, part of the flow began flowing to the northward and stopped about 100 $\mathrm{m}$ away from the hydro-technical building of the Dariali HPP (NEA 2014). The maximum speed of the flow could be $130 \mathrm{~m} / \mathrm{sec}$ (ZAAlishvili, V.B. et al. 2018).

As a result of accumulation of solid sediment transported by mudflow, a powerful debris cone occurred ( 1.5 million $\mathrm{m}^{3}$ in volume) (NEA 2014), which completely blocked the Dariali gorge (Photo 3, b). From the wall

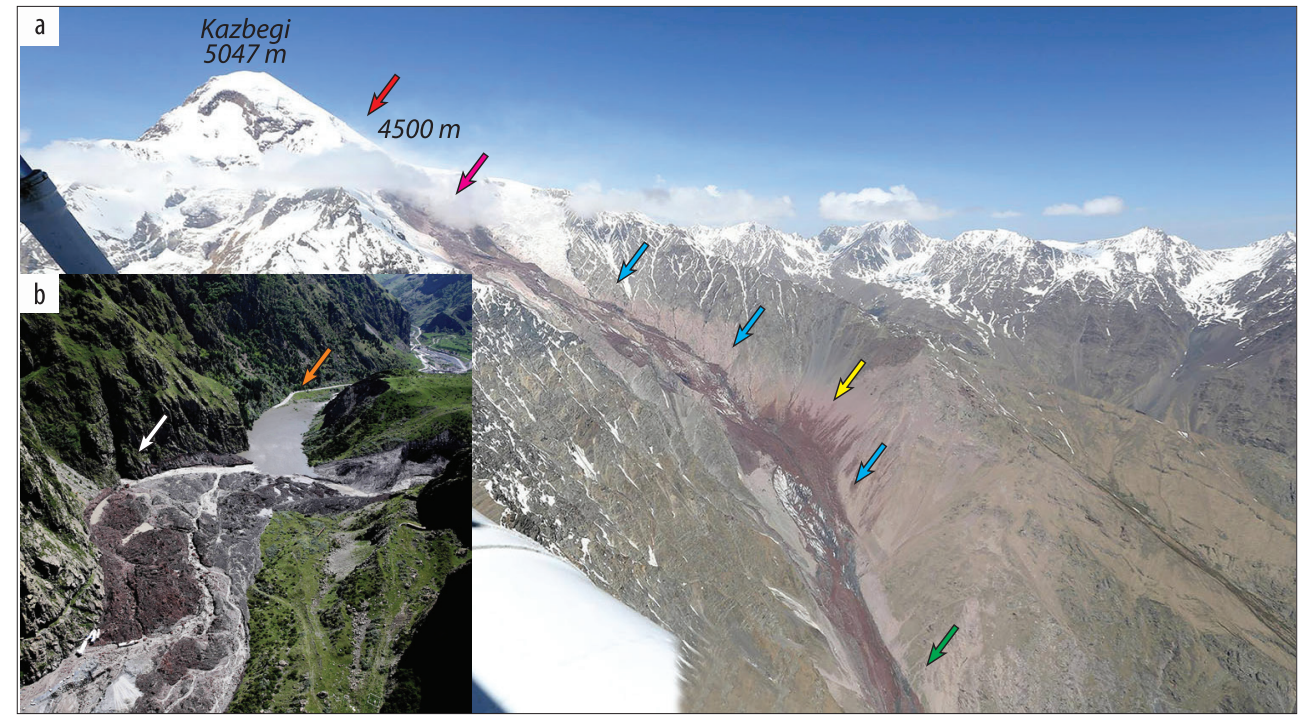

Photo 3. A helicopter photo taken on 20 May 2014 (a): red arrow indicates the origin of rock-ice avalanche; purple arrow shows accumulated material in the separation cirque area; yellow arrow shows the spraying place of the transformed material; blue arrows show accumulated material in the Devdoraki ice-tongue area; green arrow shows accumulated material in the transit zones of the gorge. Tergi (Dariali) gorge, the result of glacial-mudflow (b): white arrow shows the Dariali HPP transport tunnel from which the accumulated water flow discharged; brown arrow shows the temporary lake. Photo by Gotsinidze, G. 
of separation up to the Tergi River confluence, the overall volume of the withdrawn mudflow mass was 5-6 million $\mathrm{m}^{3}$ (NEA 2014), most of which accumulated in the area of the separated cirque and in the Devdoraki ice-tongue and transit zones of the gorge (Photo 3, a).

Overall, the Devdoraki glacial debris rock-mudflow was characterized by high density, without which and the corresponding geological nature it would be impossible to bring down large boulders (3-6 m). Moreover, even after the entry into the main river bed, the Tergi River could not provide the liquefaction of the rock-mudflow and transfer to the downstream of the river (NEA 2014). In the first stage of the accumulation of debris flow in the Tergi River gorge, the important positive role played by the transport tunnel of Dariali HPP in the passage of the dammed water flows is notable (Photo 3, b). If the water had not discharged from the temporary lake through a transport tunnel, we would have faced more catastrophic consequences.

The mudflow after its entry into the Dariali (Tergi) gorge blocked the Tergi River for some hours and a 20-30 m depth lake was created (Photo 3, b), with volume of at least $150,000 \mathrm{~m}^{3}$. The fall from the heart of rock-ice breaking to Dariali gorge (place of accumulated material) is $\sim 3.2 \mathrm{~km}$, while the distance is $\sim 10.2 \mathrm{~km}$ (see Figure 1, b). The disaster had a devastating effect over such a large inclination and distance.

At that time, Gudauri, the nearest seismic station (30 km away) from the Georgian side, recorded a 1.7 magnitude earthquake two days earlier and several hundred small quakes between 17 and 19 of May. The entire process of the movement of the avalanche flow was recorded by seismic stations of the Karmadon Parametric Range located on the Russian side in close vicinity $(\sim 14 \mathrm{~km})$ to the transit zone. Records of the station Kolka (7 km away) confirmed the time of the beginning of the collapse with an accuracy of fractions of seconds (ZAALISHVILI, V.B. et al. 2018). Location of the seismic stations is shown in Fig. 1. (a).

\section{Discussion}

\section{Avalanche triggered by tectonic and seismic movement}

Recent studies confirmed that the Devdoraki Glacier system is located within the neo-tectonic Shauhokh-Kazbegi morphostructure, developed on the left bank of the Tergi River and located at the intersection of the two largest faults and crushing zones, with which active neo-tectonic uplifts are associated (GAMKRELIDZE, I.P. 2000).

In the short valleys of the lateral tributaries of the Tergi with steep longitudinal profiles confined zones of short faults, mud-stone mudflows periodically descend, and on the slopes of valleys there are intensive landslide processes. Tectonic movements intensify the activity of gravitational and glacial processes can play a role in the movement of the Kazbegi glaciers over the last two centuries (Figure 5, a).

Comparison of recorded periods of seismic disturbance with major avalanches in the Caucasus region over the last two centuries (Mushketov, I. and Orlov, A. 1893) shows that several earthquakes occurred in 1830-1832, 1840-1842, and 1853-1856, at the time of the Kazbegi glaciers avalanches. The first period brought 17 known earthquakes to the Caucasus, the second more than 50, and the third between 30 and 40. No earthquakes at the time of the earlier avalanches of the Devdoraki Glacier have been recorded. However, southern Caucasus was not annexed by the Russian empire until 1801, and the accumulation of seismological data was naturally a gradual process. It seems possible that these earlier ice avalanches were associated with unrecorded earthquakes.

A hot spring near the Kazbegi massif adds further support to the seismic theory. Variation in both its quality and its volume, observed only a few hours before the Kolka Glacier catastrophe, observed in 1902 by inhabitants of the Genaldon Valley (Неуввоск, W. 1935), suggests a close relationship between the zone of fracture, earthquake, and glacier avalanche. 


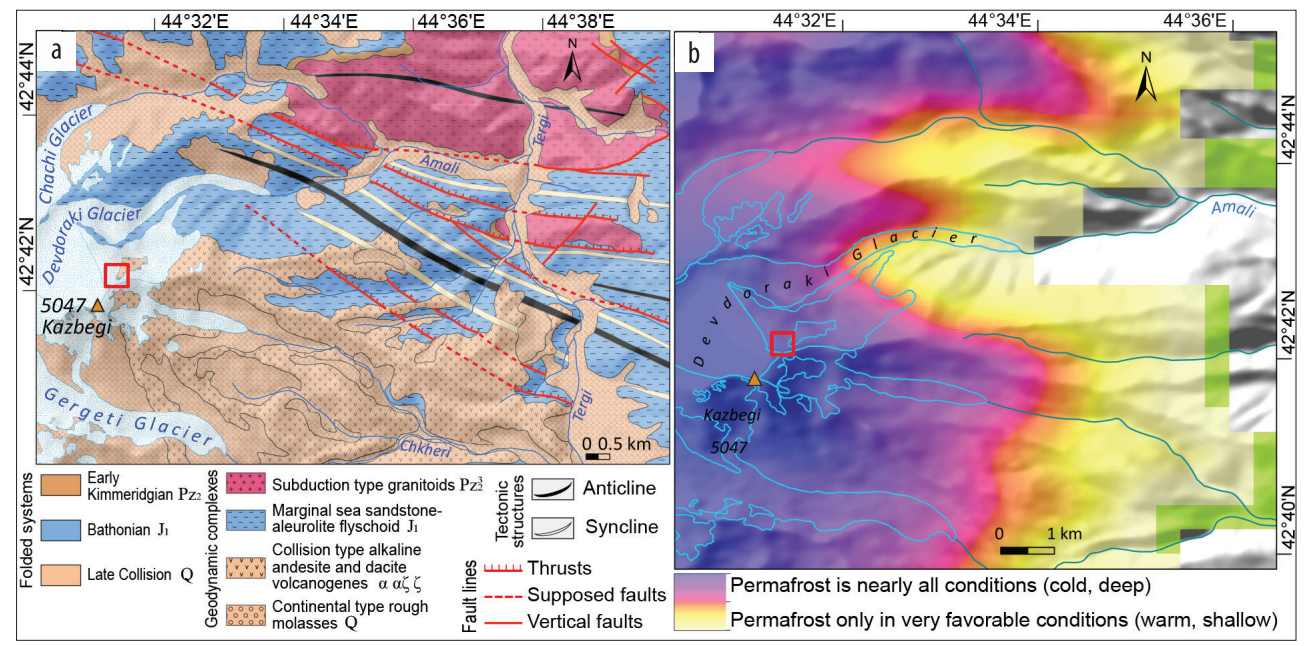

Fig. 5. Tectonic map* of the study region (a) compiled by the authors. Permafrost zonation index map (b). *The map boundaries are shown in Fig. 1.

In recent years, several volcanic tremors were recorded in the Mt. Kazbegi region (Tobler, S. and Meier, L. 2015). Such tremors may again induce slope failures on parts of the Mt. Kazbegi headwall.

\section{Avalanche triggered by permafrost and volcanic activity}

The global permafrost zonation index map (Gruber, S. 2012) shows that the avalanche start zone is located within an area of permafrost occurrence (Figure 5, b). Slope failure progressively induced by long-term degradation of permafrost is probably due to climate change (Tobler, S. and Meier, L. 2015). Degradation of permafrost can significantly reduce cohesion along frozen joints within a rock slope, causing it to destabilize.

In the aerial photographs taken on 17 May 2014 immediately after the collapse of the firn (névé) field, clouds of whitish gas flowing along the exposed cliffs of the focal region are clearly seen (Figure 6, a). On close examination, it can be asserted that these are not dust clouds and they are expelled directly from local exits in the rock substrate, i.e. fumaroles. A few hours later the emanations of gas disappeared. It is possible that the activation of fumarolic emanations occurred somewhat earlier. The outputs of the non-cold gas of endogenous nature on the contact of the rock substrate with the icefirn field were accompanied by the development of thermokarst. As this destructive process continues, the hanging ice-firn massif lost its integrity and as a consequence - strength, which led to its shedding.

These results correlate well with local people, who felt the smell of sulfur few minutes earlier before the event. However, changing tensions often provoke secondary rock-fall events on a smaller scale during the days following the main event. Such secondary rockfall events, as well as small ice detachments from the overlaying glacier can produce dust (Tobler, S. and Meier, L. 2015). Changing tensions within the rock mass after big rock failures mass may be another explanation for the visible cloud.

Further evidence of possible fumaroles is provided by ASTER imagery captured the previous day. Thermal data indicate that melting conditions had then been approached (Figure $6, \mathrm{~b})$. Thus, we can argue that the latest event is not related to the glacier surge. It was most 


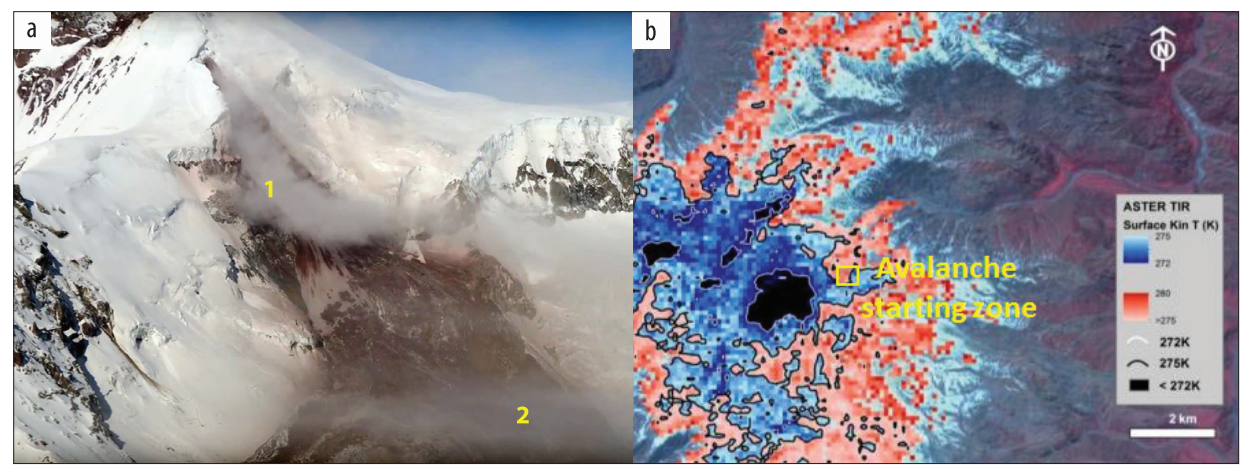

Fig. 6. Possible fumarolic emanations (a) on the north-east slopes of the Kazbegi volcano, 17 May 2014. -1 = fumaroles; 2 = stable cloud of whitish gas (presumably sulfurous). Source: Photo by Ilia State University. ASTER imagery (b) a day before (16 May 2014) the disaster (CHERNOMORETS, S.S. 2016).

likely caused by permafrost or local heat inflow from the Kazbegi massif. We note that direct evidence of such an opinion is critical for various reasons and requires more detailed investigation in the future.

\section{Avalanche triggered by slope and glacier morphology}

Analyzing the ASTER GDEM shows that the slopes of the volcanic massif of Kazbegi are sharply inclined $\left(35-60^{\circ}\right)$ up to the 3,000 m asl. This inclination causes a higher percentage $(63.8 \%)$ of hanging type glaciers in the Tergi River basin, more than other river basins in Georgia (Tielidze, L.G. 2016). Thus, the morphographic factor is also likely to have some influence. The mechanical fracturing of glaciers is frequent in the region, accelerating intensity of melting, one of the supporting factors for rock-ice avalanches.

A possible reason for the Devdoraki surging is determined by the morphology of the glacier. An extensive relatively shallow feeding area, located at altitudes of $\sim 4,000-4,700$ $\mathrm{m}$, continues below with a steeply dipping huge icefall. The ice mass and speed of its movement here are high, but then the icefall sharply narrows, and the glacier enters a narrow gorge, which causes ice accumulation.

\section{Conclusions}

Analysis of all data obtained enables conclusions about the causes and presents a possible scenario of the event. The most important circumstance has been the unusually unstable dynamics of the Devdoraki Glacier since 1776. The premature surge of the glacier and huge scale of the catastrophe were provoked by a whole complex of factors. First, this region is characterized by active movement of morphostructural blocks separated by tectonic faults, high seismic risk and the critical tension of physical fields. During the last 100 years, in the Kazbegi seismic detection block, earthquakes of 7-8 magnitude intensity were observed in 1878, 1915, 1947, 1951 and 1992 (NEA 2014). Another triggering factor was volcanic activity; apparently this caused additional melting of the bottom of the glacier and certainly favored unusually active falls from the right wall above the glacier. The tectonic and geological structure of the region also played an important role: the Devdoraki Valley is situated in a zone of large sub-latitudinal faults where displacements of individual blocks and earthquakes are highly probable along with the different relation of the volcanic and sedimentary rocks to weathering agents. A direct trigger for the glacier surge might have been just another minor 
fall, a small earthquake, or simply a destructive process inside the glacier that created a critical tension in its body.

We note that after these examinations there is a high possibility of future earthquakes and accompanying glacier avalanches in the Kazbegi region. Accordingly, future research should focus on using high resolution aerial/satellite imagery and more detailed field measurements e.g. modern seismic station installations, glacier velocity measurements, debris cover assessments, monitoring of the volcanic activity and permafrost degradation, in order to better understand how these factors are influencing glacier hazards.

To avoid serious consequences of glacier hazards we recommend to construct a road tunnel on the east (right) slope in the Tergi Valley (Figure 4, c) and to not continue the Dariali HPP construction, to mitigate the risk and avoid incidents including deaths in the future.

Acknowledgements: This work was supported by Shota Rustaveli National Science Foundation of Georgia (SRNSFG) [YS17_12].

\section{REFERENCES}

Asoyan, D.S. and Rototaeva, O.V. 2016. Devdoraki Glacier, Kazbek: history of studies of natural hazards in XIX and the beginning of XXI centuries. Ice and Snow 56. (2): 253-264. (in Russian) DOI:10.15356/2076-6734-2016-2-253-264.

Chernomorets, S.S. 2016. The Kazbek glacial debris in the Caucasus. Moscow, Moscow State University. (in Russian)

Chernyshev, I.V., Lebedev, V.A., Bubnov, S.N., Arakelyants, M.M. and Gol'tsman, Yu.V. 2002. Isotopic geochronology of Quaternary volcanic eruptions in the Greater Caucasus. Geochemistry International 40. (11): 1-16. (in Russian)

DiNIK, N.YA. 1890. Modern and ancient glaciers of the Caucasus. Tiflis, Zap. Caucasian Department of the RGO 14. (1): 282-417.

Duкноvsкiу, A.I. 1915. Observations of the Devdoraki Glacier in 1909-1912 in connection with the data on it from the $60^{\text {th }}$ of the $19^{\text {th }}$ century. Tiflis, Izv. Caucasian Department of the RGO. 23. (1): 1-21.

Dyurgerov, M.B. and Meier, M.F. 2000. Twentieth century climate change: Evidence from small glaciers. PNAS 97. (41): 406-1411. DOI: 10.1073/ pnas.97.4.1406.
Dzotsenidze, N. 1985. Volcanic formations in the report "Geological description of rivers of Liakhvi, Ksani, Aragvi and Tergi". Geological funds. (in Russian).

Evans, S.G. and Clague, J.J. 1994. Recent climatic change and catastrophic geomorphic processes in mountain environments. Geomorphology 10. 107-128.

Evans, S.G., Tutubalina, O.V., Drobyshev, V.N., Chernomorets, S.S., McDougall, S., Petrakov, D.A. and Hungr, O. 2009. Catastrophic detachment and high velocity long-runout flow of Kolka Glacier, Caucasus Mountains, Russia in 2002. Geomorphology 105. 314-321. Available at: https://doi.org/10.1016/j. geomorph.2008.10.008

GAMKRELIDZE, I.P. 2000. Again about the tectonic dismemberment of the territory of Georgia. Tbilisi, GIN NA of Georgia. (in Russian)

Gruber, S. 2012. Derivation and analysis of a high-resolution estimate of global permafrost zonation. The Cryosphere 6. 221-233. DOI:10.5194/tc-6-221-2012.

Неувrоск, W. 1935. Earthquakes as a Cause of Glacier Avalanches in the Caucasus. Geographical Review 25. (3): 423-429.

IPCC 2013. Climate change 2013: The physical science basis. Contribution of working group I to the fifth assessment report of the Intergovernmental Panel on Climate Change. Eds.: Stocker, T.F., QIN, D., Plattner, G-K., Tignor, M., Allen, S.K., Boschung, J., Nauels, A., Xia, Y., Bex, V. and Midgley, P.M. Cambridge, Cambridge University Press. DOI:10.1017/CBO9781107415324.

К $̈ \ddot{B}$, A. 2002. Monitoring high-mountain terrain deformation from repeated air and space-borne optical data: examples using digital aerial imagery and ASTER data, ISPRS J. Photogrammetry and Remote Sensing 57. 39-52.

Kä̈̈в, A., Wessels, R., Haeberli, W., Huggel, C., Kargel, J.S. and Singh Khalsa, S.J. 2003. Rapid aster imaging facilitates timely assessment of glacier hazards and disasters. Eos 84. (13): 117-124.

Kipiani, I., Avramov, K. and Iordanishvili, A. 1983. The report of the Kazbegi in two monks. Geological funds. (in Russian).

Lutz, F., Immerzeel, W.W., Shrestha, B. and Bierkens, M.F.P. 2014. Consistent increase in high Asia's runoff due to increasing glacier melt and precipitation. Nature Climate Change 4. 587-592. DOI:10.1038/ nclimate2237.

Muhlfeld, C.C., Giersch, J.J., Hauer, F.R., Pederson, G.T., Luikart, G., Peterson, D.P., Downs, C.C. and FAGRE, D.B. 2011. Climate change links fate of glaciers and an endemic alpine invertebrate. Climatic Change 106. 337-345. DOI:10.1007/s10584011-0057-1.

MushKetov, I. and Orlov, A. 1893. Katalog zemletryaseni rossiiskoi imperii (Catalogue of Earthquakes in the Russian Empire). Zapiski Imp. Russ. Geogr. Obshchestva po Obshchei Geogr. 26. (in Russian)

Nakhutsrishvili, G., Abdaladze, O. and Kikodze, A. 2005. Khevi, Kazbegi Region. Tbilisi, SCOPES Project No. GEPJ 062347. 
NEA 2014. National Environmental Agency Report, 2014. General condition of mudflow phenomena in the Tergi River upstream and the Report on the assessment of geodynamical conditions of the catastrophic glacial debris flow developed in the Dariali gorge on $17^{\text {th }}$ of May of 2014. Tbilisi, National Environmental Agency (in Georgian). Available at: http://nea.gov.ge/

Oerlemans, J. 2005. Extracting a Climate Signal from 169 Glacier Records. Science 308. 675-677. Available at: http://dx.doi.org/10.1126/science.1107046

Panov, V.D. 1993. Evolution of the modern glaciation of the Caucasus. Sankt Petersburg, Gidrometeoizdat.

Polyak, B.G., Tolstikhin, I.N., Kamensky, I.L., Yakolev, L.E., Marty, B. and Cheshoo, A.L. 2000. Helium isotopes, tectonics and heat flow in the Northern Caucasus. Geochimica et Cosmochimica Acta 64. (11): 1925-1944.

Reyneggs, D. 1884. Collection of information about the obstructions that fell from the mountain of Kazbegi from 1776 to 1878 on the Georgian Military Road. Tiflis, Typography of the Chief Directorate of the Viceroy of the Caucasus and A. Mikhelson.

Reynolds, J.M. (ed.) 2003. Development of glacial hazard and risk minimization protocol in rural environment. Report No R7816. Reynolds Geo-Sciences Ltd. UK.

Richard, D. and GAY, M. (eds.) 2003. GLACIORISK. Survey and prevention of extreme glaciological hazards in European mountainous regions. EVG1 200000512 Final report (01.01.2001-31.12.2003). Available at: htpp://glaciorisk.grenoble.cemagref.fr

StAткошsкy, B.I. 1877. Origin of Kazbegi ice blockage and measures for its prevention. Tiflis. (in Russian)

Tielidze, L.G. 2016. Glacier change over the last century, Caucasus Mountains, Georgia, observed from old topographical maps, Landsat and ASTER satellite imagery. The Cryosphere 10. 713-725. Available at: https://doi.org/10.5194/tc-10-713-2016

Tielidze, L.G. 2017. The new inventory and general description of the modern glaciers. In Glaciers of Georgia. Geography of the Physical Environment. Ed.: Tielidze, L.G., Cham, Springer. Available at: https://doi.org/10.1007/978-3-319-50571-8_3
Tielidze, L.G. and Wheate, R.D. 2018. The Greater Caucasus glacier inventory (Russia, Georgia and Azerbaijan). The Cryosphere 12. 81-94. Available at: https://doi.org/10.5194/tc-12-81-2018

Tielidze, L.G., Gobejishvili, R. and Javakhishvili, A. 2019. Eastern Greater Caucasus. In Glaciers of Georgia. Geography of the Physical Environment. Ed.: Tielidze, L.G., Cham, Springer. Available at: https://doi.org/10.1007/978-3-319-77764-1_10

Tobler, S. and Meier, L. 2015. Georgia, KazbegiDevdoraki Area. Feasibility Study for Early Warning Systems. Report Nr. 1414170.1.

Topchishvili, M.V., Lominadze, T.A., Tsereteli, I.D., Todria V.A. and Nadareishvili, G.SH. 2006 Stratigraphy of Jurassic deposits of Georgia. Tbilisi, GIN NA of Georgia. (in Russian)

Tsomaia, V.Sh. 1980. Snow transfers, pulsations of glaciers in the Caucasus mountains and their consequences. Dangerous hydro-meteorological phenomena in the Caucasus. Sankt Petersburg, Gidrometeoizdat, 176-203. (in Russian)

VARDANYANTS, L.A. 1932. Geotectonics and geoseismics of Daryal as the main cause of catastrophic landslides of the Devdoraki and Genaldon glaciers of the Kazbegi Massif. Izvestiya GGO 64. (1): 51-60.

ZaAlishvili, V.B., Melkov, D.A, Dzeranov, B.V., Morozov, F.S. and Tuaev G.E. 2018. Integrated instrumental monitoring of hazardous geological processes under the Kazbek Volcanic Center. International Journal of GEOMATE 15. (47): 158-163.

Zautashvili, B. and MkHeidze, B. 2012. Mineral waters. Chapter in the National Atlas of Georgia. Tbilisi, Publ. "Cartograpia". (in Georgian) 
